\title{
A universal meteorological method to identify potential risk of wind erosion on heavy-textured soils
}

\author{
Hana STŘEDOVÁ a* , Bronislava SPÁČILOVÁ a , Jana PODHRÁZSKÁ ${ }^{\mathrm{b}}$, Filip CHUCHMA ${ }^{\mathrm{c}}$
}

\begin{abstract}
The climate of Central Europe, mainly winter seasons with no snow cover at lower altitudes and a spring drought as well, might cause erosion events on heavy-textured soils. The aim of this paper is to define a universal method to identify the potential risk of wind erosion on heavy-textured soils. The categorization of potential wind erosion risk due to meteorological conditions is based on: (i) an evaluation of the number of freeze-thaw episodes forming bare soil surfaces during the cold period of year; and (ii), an evaluation of the number of days with wet soil surfaces during the cold period of year. In the period 2001-2012 (from November to March), episodes with temperature changes from positive to negative and vice versa (thaw-freeze and freezethaw cycles) and the effects of wet soil surfaces in connection with aggregate disintegration, are identified. The data are spatially interpolated by GIS tools for areas in the Czech Republic with heavy-textured soils. Blending critical categories is used to locate potential risks. The level of risk is divided into six classes. Those areas identified as potentially most vulnerable are the same localities where the highest number of erosive episodes on heavy-textured soils was documented.
\end{abstract}

Keywords: freeze-thaw cycle, soil moisture, aggregate stability, clay soil, meteorological conditions, GIS tools

\section{Introduction}

The erodibility of soil by wind depends primarily on soil texture, or the relative proportion of sand, silt and clay (Chepil, 1952), the size and stability of soil aggregates (Skidmore and Powers, 1982; Colazo and Buschiazzo, 2010, Amézketa et al., 2003), and crusting (Fan et al., 2008). Key factors for the degradation of aggregate stability and deterioration of soil structure are excess water, stability and water resistance of aggregates given by the content of bonding compounds (organic matter, divalent cations), $\mathrm{pH}$, crop residues and mechanical cultivation interventions. These processes (effects of water, drought, frost, $\mathrm{CaCO}_{3}$, and organic matter on the stability of aggregates, etc.) were studied and their principles were described in the scientific literature from the 1930s to the 1950s (Yoder, 1936; Chepil, 1951, 1952, 1953, 1954, 1958).

In loams and clay loams, seals and crusts decrease roughness but increase surface soil strength, generally decreasing wind erosion (Singer and Shainberg, 2004). The clay-loam soil in a study by Anderson and Wenhardt (1966) was significantly less erodible in the spring than it was in the previous fall, indicating overwinter aggregation of the erodible fraction. On the contrary, Bullock et al. (2001) found an increasing amount of erodible particles after winter and spring seasons of up to $25 \%$ in heavy-textured clay-loam soils. The greatest change of erodibility occurred during the period with snow cover, when the occasional snowmelt increased water content and allowed a more effective disintegration of aggregates in the cycle of freeze-thaw.

It is thus clear that the course of meteorological characteristics in winter is a factor that contributes to wind erosion on heavy-textured soils. Changes in soil surface aggregation during winter can result in surface conditions highly susceptible or resistant to wind erosion, depending on the overwinter processes (Tatarko et al., 2001).

Due to alternating freezing and thawing of the soil surface, there occurs a significant collapse of soil structure on Haplic Chernozem (Siltic), Haplic Chernozem (Clayic), Haplic Cambisol (Clayic) (IUSS, 2006; Vopravil et al., 2007) primarily in the winter period, and so soils generally considered as invulnerable to wind erosion (Chepil, 1953) due to grain size, are highly threatened by wind erosion. These represent an anomaly, because heavy-textured soils are generally not susceptible to wind erosion. In certain weather conditions, however, and due to improper management, wind erosion also affects clay soils (Bullock et al., 1999).

There are many studies dealing with the effects of freezethaw processes on different soil characteristics (e.g. Logsdail and Webber, 1959; DeLuca et al., 1992; Grogan et al., 2004; Bechmann et al., 2005; Oztas and Fayetorbay, 2003; Sjursen et al., 2005; Melick and Seppelt, 1992; Xiuqing and Flerchinger, 2001; Bullock et al., 1999; Kværnø and Øygarden, 2006). The destructive effects of alternate freezing and thawing, in general, increase with increasing moisture in well-aggregated soils (Logsdail and Webber, 1959). Oztas and Fayetorbay (2003) confirmed that the moisture content of aggregate samples significantly influenced their stability on freezing. The aggregates in soils having a moisture content near saturation on freezing will be easily dispersed after thawing. These results agree with others. Benoit (1973) reported that the largest decrease in aggregate stability occurred when soil was at the maximum water holding content, and Lehrsch et al. (1991) found that the aggregate stability of fine- and medium-textured soils decreased linearly with increasing initial moisture content.

\footnotetext{
${ }^{a}$ Mendel University in Brno, Institute of Applied and Landscape Ecology, Brno, Czech Republic

(*corresponding author: H. Stř̌edová, e-mail: hana.stredova@mendelu.cz)

${ }^{\mathrm{b}}$ Research Institute for Soil and Water Conservation, Brno, Czech Republic

${ }^{\mathrm{c}}$ Czech Hydrometeorological Institute, Brno, Czech Republic
} 
In this context, water content is also one of the major factors involved in the aggregation process (Hartmann and de Boodt, 1974) and soil cohesion (Nimmo, 2005). BravoGarza et al. (2009) showed the important role of wetting and drying cycles in the formation and stabilization of large macro-aggregates after organic amendment. Another role of moisture in wind erosion is that rain often carries some of the finely dispersed, water-soluble cementing materials downward in the profile, leaving coarse particles such as sand and water-stable aggregates at the top (Hagen et al., 1988), and moving water has also the capacity to destroy soil aggregates (Murray and Grant, 2007). Quick wetting of aggregates leads to aggregate breakdown (Borůvka et al., 2002; Diaz-Zorita et al., 2002; Kemper and Rosenau, 1986). The laboratory analyses of heavytextured soils (Bullock et al., 1999) showed the considerable importance of sublimation drying on the destruction of soil aggregates. The conclusions from the experiment of Dagesse (2013) showed that the freezing-induced desiccation process improves aggregate stability, while the addition of a thaw component following freezing, with the attendant liquid water, is responsible for the degradation of aggregate stability.

The main objectives of this paper are as follows: (i) to develop a relevant method for estimation of potential risk of wind erosion on heavy-textured soils based on commonlyavailable meteorological data; (ii) to categorize areas in the Czech Republic according to the potential risk of wind erosion on heavy-textured soils, using GIS; and (iii) to compare the results obtained with historical observations of actual wind erosion records on heavy-textured soils.

\section{Materials and methods}

The specification of endangered areas and categorization of potential erosion risk on clay soils and clay loam soils (further, heavy-textured soils) due to meteorological conditions is based on an evaluation of the "condition of bare soil surface" layer (Tab. 1), in combination with temperature conditions. The condition of the bare soil surface is a phenomenon observed at stations of the Czech Hydrometeorological Institute. The condition of the soil surface signifies the consistency properties of the surface soil layer, i.e. the state and moisture of the bare soil surface (Mužíková et al., 2013; Spáčilová et al., 2014). In frost-free periods, it is mainly determined by liquid precipitation in winter, by frost, snow cover and its parameters (i.e. snow covering, rate of snow-thawing, snow-water content: Pokladníková et al., 2008). The greatest advantage of these data is their continuous everyday information (observed at $7 \mathrm{AM}$, at $2 \mathrm{PM}$, at $9 \mathrm{PM}$ ) on the surface soil layer. Observation of the soil is done at the station plots and in their vicinities.

For each cold part of the year, from November to March, for the period 2001-2012, the number of episodes with observed changes in temperature from positive to negative and vice versa (i.e. freeze-thaw and thaw-freeze episodes) was identified. Hourly data on air temperature at $2 \mathrm{~m}$ above the ground were used. A measurement height at $1.2-2.0 \mathrm{~m}$ above ground is the standard recommended by the World Meteorological Organization (WMO, 2008), and land surface temperatures are found to be very well correlated with air temperatures 1-3 $\mathrm{m}$ above the ground (Hachem et al., 2012). Applications of the described method are thus possible in wide range of countries. With respect to the thermal insulative properties of snow, the number of episodes of 'freeze-thaw' was evaluated only for days without snow cover.

This study evaluated data for each year but from a different number of stations, because since the year 2000 automatic stations have been gradually added into the network (for the season 2001-2002 only 71 stations were used, but for the season 2011-2012, 142 stations were used). Meteorological point measurements and observations were interpolated by using GIS tools (ArcGIS 10.3). On the basis of these data, 11 raster layers for each cold period were created, using the method of local linear regression depending on the altitude and corrected estimated value with variation, in order to preserve the values corresponding to the location of the station. These layers at a spatial resolution of $100 \times 100 \mathrm{~m}$ were then averaged for the entire period 2001-2012, and the values were assigned to the given areas with occurrence of heavy-textured soils (Vopravil, 2011).

Similarly, the effect of the dispersion of aggregates due to the wet soil surface was evaluated. With regard to this, the following soil surface states were defined as the critical conditions: number of days with soil condition 2 (wet soil surface - soaked - water in smaller or larger pools); soil condition 5 (snow or melting snow with ice or without ice covers less soil surface than a half); and soil condition 6 (snow or melting snow with ice or without ice covers more than a half of soil surface, but not entirely: see Tab. 1). A concurrent condition was the maximum daily air temperature exceeding $0{ }^{\circ} \mathrm{C}$ (liquid water). Data from 126 stations across the country were evaluated. Interpolation was carried out for the whole territory of the Czech Republic and the resulting values were assigned to the given areas with occurrence of heavy-textured soils.

\begin{tabular}{|c|l|}
\hline Code & \multicolumn{1}{|c|}{ Characterization } \\
\hline 0 & Dry soil surface \\
1 & Wet soil surface \\
2 & Wet (soaked) soil surface (water is present in puddles) \\
3 & Soil surface is bare and frozen \\
4 & Soil covered by ice, without snow or thawing snow \\
5 & Snow or thawing snow (with or without ice) covers less than half of soil surface \\
6 & Snow or thawing snow (with or without ice) covers more than half of soil surface, but not completely \\
7 & Snow or thawing snow (with or without ice) covers soil surface completely \\
8 & Dry, loose snow covers more than half of soil surface, but not completely \\
9 & Dry, loose snow covers soil surface completely \\
\hline
\end{tabular}

Tab. 1: Condition of bare soil surface classification. Source: based on Slabá, 1972 
To ensure compatibility with erosion risk on light soils (Podhrázská et al., 2013), both characteristic values were divided into five categories, from the lowest to the highest number of days or episodes. Erosive risk evaluation requires taking into consideration the synergic effect of critical conditions. Blending the categories (Tab. 2) was used to locate potential risks in the cadastre with an occurrence of heavy-textured soils. Six categories were defined to quantify the level of risk. Category 1 signifies the lowest risk, labelled "No threat soils", category 2 is labelled "Susceptible soils", category 3 "Slightly susceptible soils", category 4 "Endangered soils", category 5 "Severely endangered soils", and category 6 represents the highest erosion risk, labelled as "Most endangered soils".

\section{Results and discussion}

The results, presented cartographically, show the regional differences in winter conditions that lead to increased potential soil erodibility. According to the data on soil conditions from meteorological stations across the country, five categories of occurrence of episodes with air temperature changes from positive to negative and vice versa during the days without snow, were identified (Fig. 1). Soil freezing causes disintegration of aggregates due to physical forces, while thawing causes aggregate disintegration by liquid water. Therefore, the episodes freeze-thaw and thaw-freeze were taken into consideration, and their number and interrelations were evaluated.

The highest values are 95 episodes and they decrease to 35 episodes in the cold part of the year (Fig. 1). Similarly, Hershfield (1974) used data from 1300 climatic stations to construct a map of annual frequency of freeze-thaw cycles in the USA. The number of freeze-thaw cycles (days per year) ranged from less than 20 to 250 .

Heavy-textured soils with the highest number of episodes (about 90 episodes with such conditions of soil: red colour in the Fig. 1) were found in the southeast part of the Czech Republic, and there is also a small area in the north-western part of the Czech Republic. These results correspond very well with the fact that wind erosion has been often observed and measured at these localities (Mužíková et al., 2010; Švehlík, 1985; Vopravil et al., 2007). In specific areas, the erosion loss of $2 \mathrm{~mm}$ aggregates could be expected. This size is the limit of erodibility in heavy-textured soils of the Czech Republic under certain conditions (Švehlík, 1985). Edwards (2013) stated that practically no change in soil aggregate size fraction after 15 freeze-thaw cycles for a size aggregate less than $2 \mathrm{~mm}$ could be observed. Although a certain number of freeze-thaw cycles may be beneficial for the surface soil structures of wet soil, Oztas and Fayetorbay (2003) reported that wet aggregate stability generally increased when the number of freezing and thawing cycles increased from 3 to 6 , but decreased after that point. Similarly, Lehrsch (1998) pointed out that aggregate stability would be greatest after two or three freeze-thaw cycles. Wang et al. (2012) found that after nine cycles of freezing and thawing, the mean weight diameter of wet aggregates and stability increased slightly compared with three cycles of freezing and thawing.

The wind erosion occurs during the dormancy period when the fields are without plant cover, especially at the beginning of the year and in early spring. The greatest number of days with wind erosion occurs in this area in

\begin{tabular}{|c|c|c|c|c|c|c|}
\hline & & \multicolumn{5}{|c|}{ Categories according to Fig. 1} \\
\hline & & 1 & 2 & 3 & 4 & 5 \\
\hline \multirow{5}{*}{ 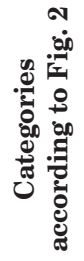 } & 1 & 1 & 1 & 2 & 3 & 4 \\
\hline & 2 & 1 & 2 & 3 & 4 & 5 \\
\hline & 3 & 2 & 3 & 4 & 5 & 6 \\
\hline & 4 & 3 & 4 & 5 & 6 & 6 \\
\hline & 5 & 4 & 5 & 6 & 6 & 6 \\
\hline
\end{tabular}

Tab. 2: Categorization of the potential risk to wind erosion based on input data (Figs. 1 and 2). Source: authors

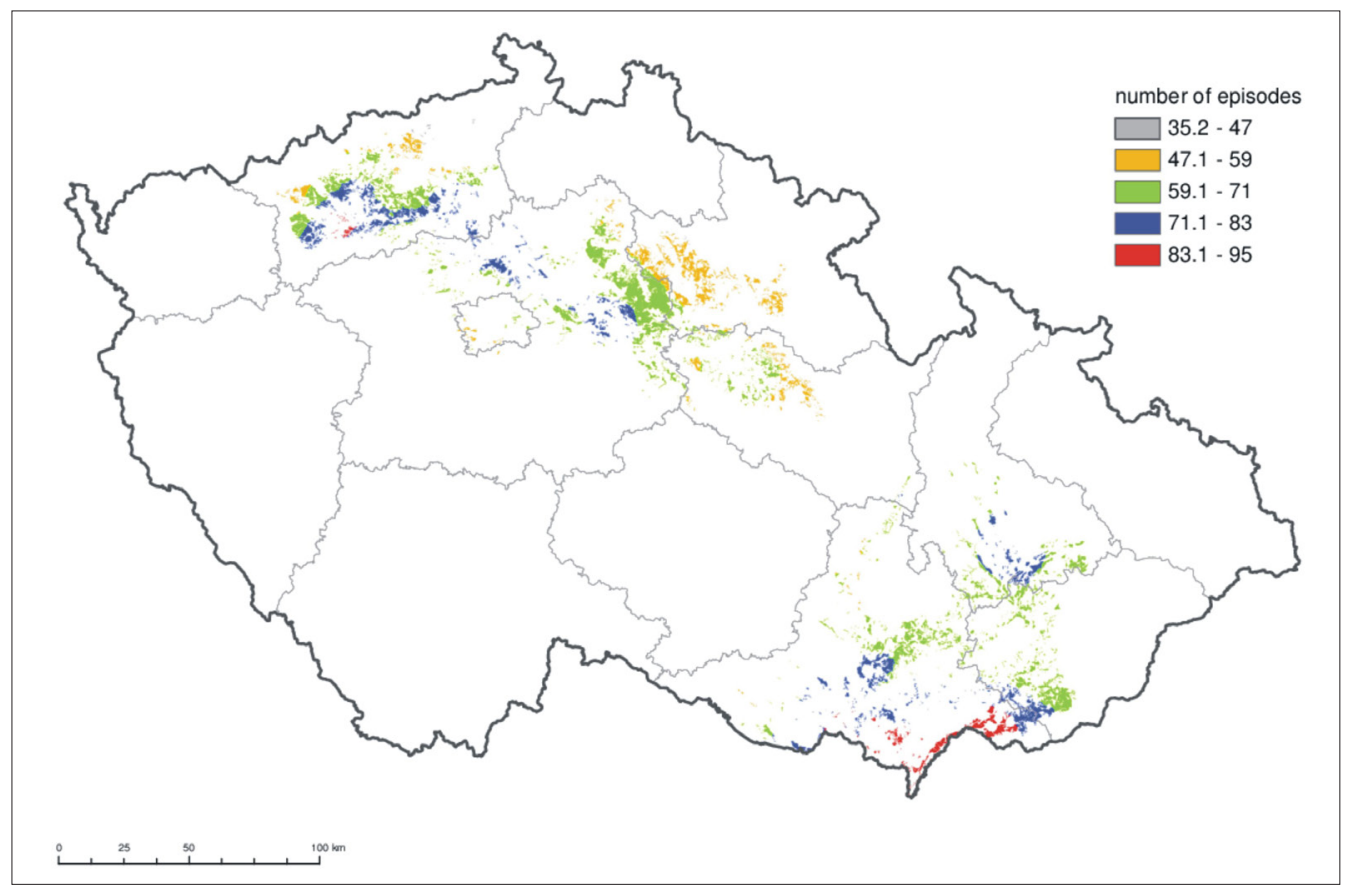

Fig. 1: Average seasonal number of episodes freeze-thaw and thaw-freeze during the days without snow cover Source: authors 
March (up to $30 \%$ ), January (23\%), and $20 \%$ in February and April (Mužíková et al., 2010). Moreover, Středová et al. (2011) found out an increasing drought event probability (mainly in spring) in the period 1961-2010, compared to 1961-1990 for the Czech Republic.

In a second step, the number of days with vulnerable soil conditions (2, 5 and 6$)$ during days with maximum daily air temperature exceeding $0{ }^{\circ} \mathrm{C}$ (liquid water), was evaluated. Some regions are characterized by the occurrence of only a few days with such conditions in winter and early spring. On the other hand, in the central part of the Czech Republic there are many localities with more than 50 days of such conditions. The high number of days with wet soil surface (blue colour in Fig. 2) was identified in the southeast part of the Czech Republic (just as in the case of freeze-thaw).

The synergic effect of individual factors (number of episodes freeze-thaw and number of days with wet soil surface) must be also taken into account. Laboratory investigation of a clay soil indicated that the percentage of aggregates less than $1 \mathrm{~mm}$ might be influenced by freezing and thawing depending on the initial moisture content (Hinman and Bisal, 1968). It was one of the reasons to create Fig. 3, which represents the synergic effect of both factors. A synthetic map (Fig. 3) presents potential wind erosion risk of heavy-textured soils

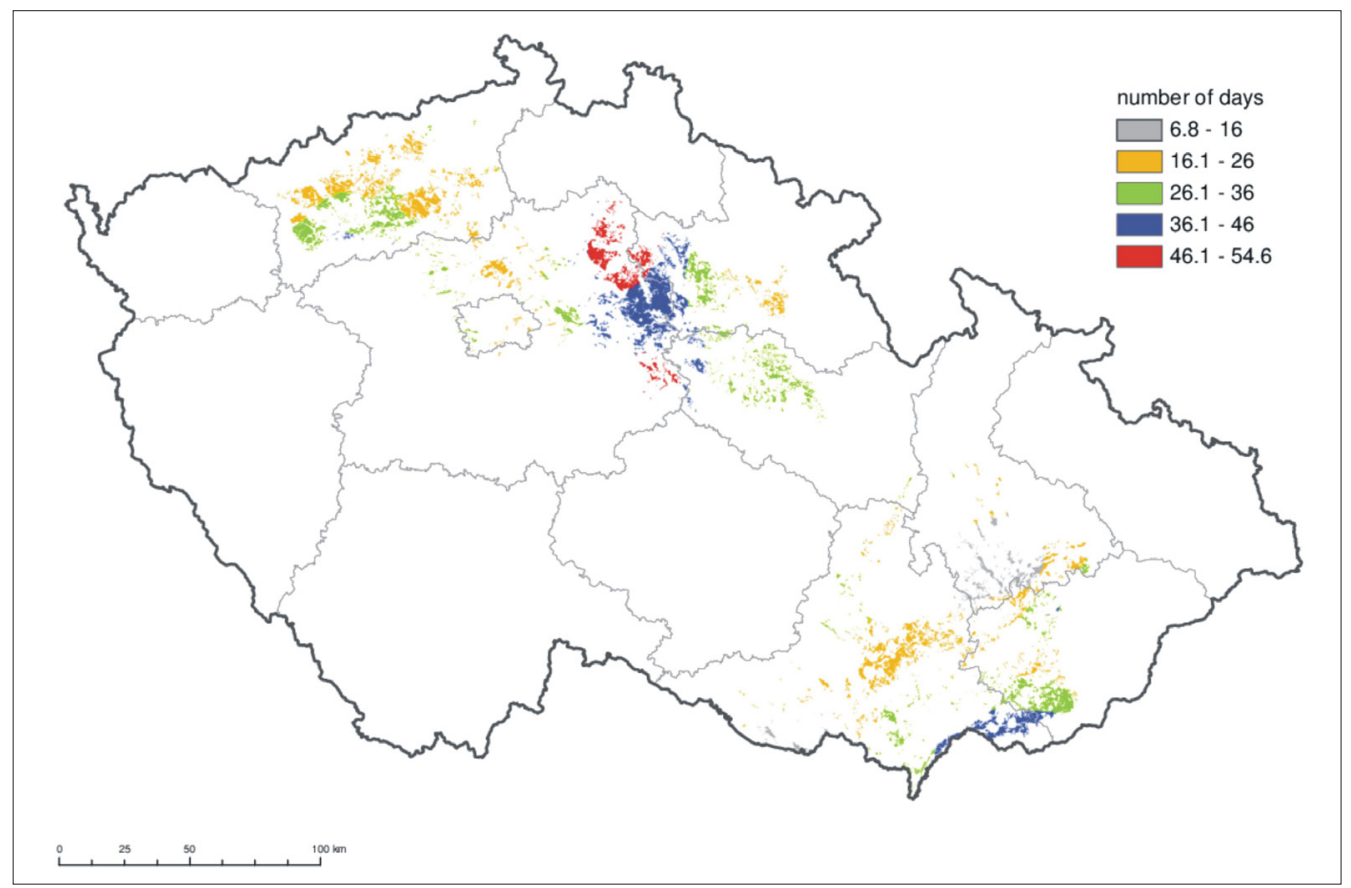

Fig. 2: Average seasonal number of days with wet soil surface, allowing the soil aggregates dispersion Source: authors

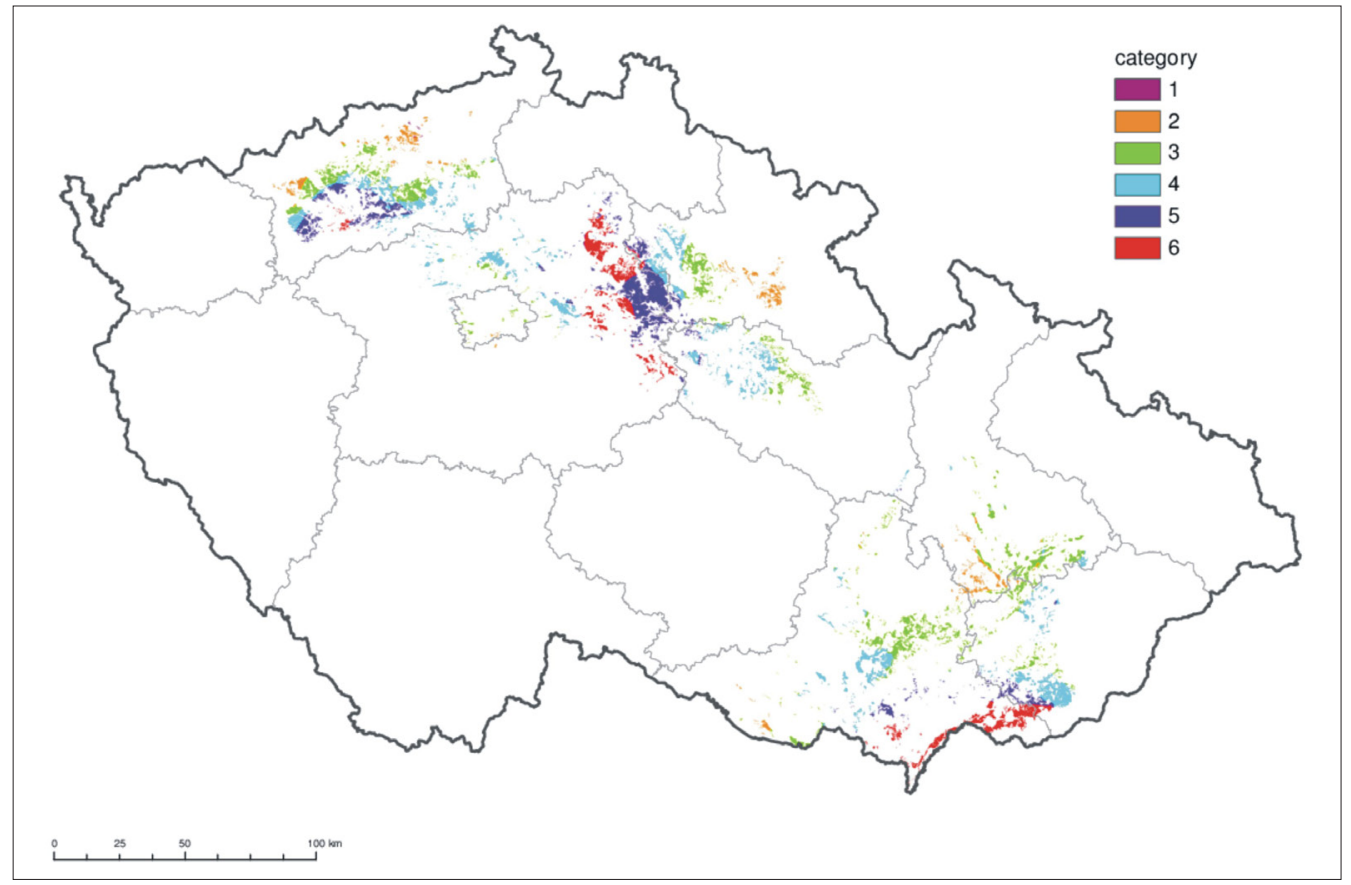

Fig. 3: Resulting map of potential wind erosion risk on heavy-textured soils Source: authors 
on the basis of the relevant meteorological characteristics presented above. It was formed as an intersection of two map layers - Figs. 1 and 2 - categorized into six categories based on the erosion risk matrix in Tab. 2.

An analogical attitude to the evaluation of spatial erosion risk, including the effects of vegetation and relief, has been applied and recommended by Kong and Yu (2013). Using a similar concept (GIS and remote sensing analysis of the number of snow cover days, soil erodibility, aridity and other factors), the study by Zhou et al. (2015) reveals that wind erosion has aggravated recently. Applications to available extensions provide a flexible model for a wide range of pedological, microbiological, environmental, agricultural and other analyses.

Current sophisticated maps of erosion risk in European countries (for example, Borelli et al. (2014) for 25 member states of the European Union, or Bielek et al. (2005) for the Slovak Republic), do not take into account erosion risk on heavy textured soils. It is generally assumed that wind erosion risk is relevant only for sandy and loamy-sand soils. The methodology presented in this study, however, enables an erosion risk determination for European countries also for heavy textured soils.

\section{Conclusions}

Meteorological data from stations across the Czech Republic enabled the spatial characterization of winter conditions, which may lead to wind erosion events on heavytextured soils.

The most vulnerable areas according to the high number of days with occurrence of soil conditions, allowing for the soil aggregates dispersion, are in the north-western and south-eastern part of the Czech Republic. These areas are often also locations with a high number of episodes of freezethaw cycles during winter and early spring, and are therefore the areas with the highest potential wind erosion risk. These results correspond very well with the fact that wind erosion has been often observed and measured at these localities.

Applications of the methods described above are possible in a wide range of countries with similar approaches to and methodologies of climatic elements monitoring.

\section{Acknowledgement}

This paper was supported by a project of the Ministry of Agriculture of the Czech Republic: QJ1220054: "Impact of a change of climatic factors on the development of wind erosion processes, conceptual solution through the land adjustment measures". The authors would like to thank the anonymous reviewers for their helpful and constructive comments that greatly contributed to improving the final version of the paper. They would also like to thank the editors for their comments and support during the review process.

\section{References:}

AMÉZKETA, E., ARAGÜÉS, R., CARRANZA, R., URGEL, B. (2003): Macro- and micro-aggregate stability of soils determined by a combination of wet-sieving and laser-ray diffraction. Spanish Journal of Agricultural Research, 1: 83-94.

ANDERSON, C. H., WENHARDT, A. (1966): Soil erodibility, fall and spring. Canadian Journal of Soil Science, 46(3): $255-259$.
BECHMANN, M. E., KLEINMAN, P. J., SHARPLEY, A. N., SAPORITO, L. S. (2005): Freeze-thaw effects on phosphorus loss in runoff from manured and catchcropped soils. Journal of Environmental Quality, 34(6): 2301-2309.

BENOIT, G. R. (1973): Effect of freeze-thaw cycles on aggregate stability and hydraulic conductivity of three soil aggregate sizes. Soil Science Society of America Proceedings, 37(1): 3-5.

BIELEK, P., ČURLÍK, J., FULAJTÁR, E., HOUŠKOVÁ, B., ILAVSKÁ, B., KOBZA, J. (2005): Soil survey and managing of soil data in Slovakia. In: Soil resources of Europe, second edition. Research report No. 9 (pp. 317-329). The European Soil Bureau, Ispra, Italy.

BORELLI, P., BALLABIO, C., PANAGOS, P., MONTANARELLA, L. (2014): Wind erosion susceptibility of European soils. Geoderma, 232234: 471-478.

BORU゚VKA, L., VALLA, M., DONÁTOVÁ, H., NĚMEČEK, K. (2002): Vulnerability of soil aggregates in relation to soil properties. Rostlinná Výroba, 48(8): 329-334.

BRAVO-GARZA， M. R., BRYAN， R. B., VORONEY, P. (2009): Influence of wetting and drying cycles and maize residue addition on the formation of water stable aggregates in Vertisols. Geoderma, 151(3-4): 150-156.

BULLOCK, M. S., LARNEY, F. J., IZAURRALDE, R. C., FENG, Y. (2001): Overwinter changes in wind erodibility of clay loam soils in southern Alberta. Soil Science Society of America Journal, 65(2): 423-430.

BULLOCK, M. S., LARNEY, F. J., McGINN, S. M., IZAURRALDE, R. C. (1999): Freeze-drying processes and wind erodibility of a clay loam soil in southern Alberta. Canadian Journal of Soil Science, 79(1): 127-135.

CHEPIL, W. S. (1951): Properties of soil which influence wind erosion: V. Mechanical stability of structure. Soil Science, Vol. 72: 465-478.

CHEPIL, W. S. (1952): Improved rotary sieve for measuring state and stability of dry soil structure. Soil Science Society of America Proceedings, 16(2): 113-117.

CHEPIL, W. S. (1953): Factors that influence clod structure and erodibility of soil by wind: I. Soil structure. Soil Science, 75: 473-483.

CHEPIL, W. S. (1954): Seasonal fluctuations in soil structure and erodibility of soil by wind. Soil Science Society of America Proceedings, 18(1): 13-16.

CHEPIL, W. S. (1958): Soil conditions that influence wind erosion. Technical Bulletin, No. 1185. Washington, D.C., USA, United States Department of Agriculture.

COLAZO, J. C., BUSCHIAZZO, D. E. (2010): Soil dry aggregate stability and wind erodible fraction in a semiarid environment of Argentina. Geoderma, 159(1-2): 228236.

DAGESSE, D. F. (2013): Freezing cycle effects on water stability of soil aggregates. Canadian Journal of Soil Science, 93(4):473-483.

DeLUCA, T. H., KEENEY, D. R., McCARTY, G. W. (1992): Effect of freeze-thaw events on mineralization of soil nitrogen. Biology and Fertility of Soils, 14(2): 116-120. 
DIAZ-ZORITA, M., GROVE, J. H., PERFECT, E. (2002): Aggregation, fragmentation, and structural stability measurement. In: Encyclopedia of Soil Science (pp. 3740). Marcel Dekker, Inc., New York, USA.

EDWARDS, L. M. (2013): The effects of soil freeze-thaw on soil aggregate breakdown and concomitant sediment flow in Prince Edward Island: A review. Canadian Journal of Soil Science, 93(4): 459-472.

FAN, Y., LIU, J., CAI, Q. (2008): The effects of wetting rate on aggregate stability in three soils. In: $15^{\text {th }}$ ISCO Congress "Soil and Water Conservation, Climate Change and Environmental Sensitivity", 1823 May 2008 Budapest (p. 4). Geographical Research Institute, Hungarian Academy of Science, Budapest, Hungary.

GROGAN, P., MICHELSEN, A., AMBUS, P., JONASSON, S. (2004): Freeze-thaw regime effects on carbon and nitrogen dynamics in sub-arctic heath tundra mesocosms. Soil Biology and Biochemistry, 36: 641-654.

HACHEM, S., DUGUAY, C. R., ALLARD, M. (2012): Comparison of MODIS-derived land surface temperatures with ground surface and air temperature measurements in continuous permafrost terrain. The Cryosphere, 6: 51-69.

HAGEN, L. J., SKIDMORE, E. L., LAYTON, J. B. (1988) Wind erosion abrasion: effects of aggregate moisture. Transactions of the ASAE, 31(3): 725-728.

HARTMANN, R., DE BOODT, M. (1974): The influence of the moisture content, texture and organic matter on the aggregation of sandy and loamy soils. Geoderma, 11(1): 53-62.

HERSHFIELD, D. M. (1974): The frequency of freeze-thaw cycles. Journal of Applied Meteorology, 13: 348-354.

HINMAN, W. C., BISAL, F. (1968): Alterations of soil structure upon freezing and thawing and subsequent drying. Canadian Journal of Soil Science, 48(2): 193-197.

IUSS Working Group WRB (2006): World reference base for soil resources 2006. World Soil Resources Reports No. 103. FAO, Rome, Italy.

KEMPER, W. D., ROSENAU, R. C. (1986): Aggregate stability and size distribution. In: Methods of Soil Analysis, Part 1. Physical and Mineralogical Methods (pp. 425-444). American Society of Agronomy, Madison, USA.

KONG, B., YU, H. (2013): Estimation model of soil freezethaw erosion in Silingco Watershed Wetland of Northern Tibet. The Scientific World Journal, ID 636521.

KVÆRNØ, S. H., ØYGARDEN, L. (2006): The influence of freeze-thaw cycles and soil moisture on aggregate stability of three soils in Norway. Catena, 67(3): 175-182.

LEHRSCH, G. A. (1998): Freeze/thaw cycles increase nearsurface aggregate stability. Soil Science, 163(1): 63-70.

LEHRSCH， G. A., SOJKA, R. E., CARTER, D. L., JOLLEY, P. M. (1991): Freezing effects on aggregate stability affected by texture, mineralogy, and organic matter. Soil Science Society of America Journal, 55(5): 1401-1406.

LOGSDAIL, D. E., WEBBER, L. R. (1959): Effect of frost action on structure of Haldimand clay. Canadian Journal of Soil Science, 39(2): 103-106.
MELICK, D. R., SEPPELT, R. D. (1992): Loss of soluble carbohydrates and changes in freezing point of Antarctic bryophytes after leaching and repeated freeze-thaw cycles. Antarctic Science, 4(4): 399-404.

MURRAY, R. S., GRANT, C.D. (2007): The impact of irrigation on soil structure. The National Program for Sustainable Irrigation (Land and Water Australia), Canberra, Australia.

MUŽÍKOVÁ, B., STŘEDA, T., PODHRÁZSKÁ, J., TOMAN, F. (2010): Meteorological conditions during extreme wind erosion events on heavy soils. Acta Universitatis Agriculturae et Silviculturae Mendelianae Brunensis, 58(1): 115-122.

MUŽÍKOVÁ, B., STŘEDA, T., STŘEDOVÁ, H. (2013): State of bare soil surface as a spring drought indicator. Contributions to Geophysics and Geodesy, 43(3): 197-207.

NIMMO, J. R. (2005): Aggregation: Physical Aspects. In: Encyclopedia of Soils in the Environment (pp. 28-35). London, Academic Press.

OZTAS, T., FAYETORBAY, F. (2003): Effect of freezing and thawing processes on soil aggregate stability. Catena, 52(1): 1-8.

PODHRÁZSKÁ, J., KUČERA, J., CHUCHMA, F., STŘEDA, T., STŘEDOVÁ, H. (2013): Effect of changes in some climatic factors on wind erosion risks - the case study of South Moravia. Acta Universitatis Agriculturae et Silviculturae Mendelianae Brunensis, 61(6): 1829-1837.

POKLADNÍKOVÁ, H., TOMAN, F., STŘEDA, T. (2008): Negative impacts of snowmelting on the soil. Acta Universitatis Agriculturae et Silviculturae Mendelianae Brunensis, 56(1):143-148.

SINGER, M. J., SHAINBERG, I. (2004): Mineral soil surface crusts and wind and water erosion. Earth Surface Processes and Landforms, 29(9): 1065-1075.

SJURSEN, H., MICHELSEN, A., HOLMSTRUP, M. (2005): Effects of freeze-thaw cycles on microarthropods and nutrient availability in a sub-Arctic soil. Applied Soil Ecology, 28(1): 79-93.

SKIDMORE, E. L., POWERS, D. H. (1982): Dry soilaggregate stability: energy-based index. Soil Science Society of America Journal, 46: 1274-1279.

SLABÁ, N. (1972): Návod pro pozorovatele meteorologických stanic ČSSR. 2. přepracované vydání. Sborníky předpisů Hydrometeorologického ústavu v Praze, Svazek 7. Praha: Hydrometeorologický ústav.

SPÁČILOVÁ, B., STŘEDA, T., THONNOVÁ, P. (2014): Spatial expression of potential wind erosion threats to arable soils in the Czech Republic. Contributions to Geophysics and Geodesy, 44(3): 241-252.

STŘEDOVÁ, H., CHUCHMA, F., STŘEDA, T. (2011): Climatic factors of soil estimated system. Bioclimate: Source and limit of social development (pp. 137-138). Topolčianky, Slovakia.

ŠVEHLÍK, R. (1985): Větrná eroze půdy na jihovýchodní Moravě. Zabraňujeme škodám. Praha, SZN.

TATARKO, J., WAGNER, L. E., BOYCE, C. A. (2001): Effects of overwinter processes on stability of dry soil aggregates. In: Soil Erosion Research for the $21^{\text {st }}$ Century (pp. 459462). Honolulu, ASABE. 
VOPRAVIL, J. [ed.] (2011): Půda a její hodnocení v ČR, díl II. Praha, VÚMOP, v.v.i.

VOPRAVIL, J., JANEČEK, M., TIPPL, M. (2007): Revised soil erodibility K-factor for soils in the Czech Republic. Soil and Water Research, 2(1): 1-9.

WANG, E., CRUSE, R. M., CHEN, X., DAIGH, A. (2012): Effects of moisture condition and freeze/thaw cycles on surface soil aggregate size distribution and stability. Canadian Journal of Soil Science, 92(3): 529-536.

WMO (2008): Guide to meteorological instruments and methods of observation. WMO, No. 8. World Meteorological Organization, Geneva.
XIUQING, Z., FLERCHINGER, G. (2001): Infiltration into freezing and thawing soils under differing field treatments. Journal of Irrigation and Drainage Engineering, 127(3): 176-182.

YODER, R.E. (1936): A direct method of aggregate analysis and a study of the physical nature of erosion losses. Journal of the American Society of Agronomy, 28: 337-351.

ZHOU, Y., GUO, B., WANG, S., TAO, H. (2015): An estimation method of soil wind erosion in Inner Mongolia of China based on geographic information system and remote sensing. Journal of Arid Land, 7(3): 304-317.

Initial submission 10 July 2014, final acceptance 14 April 2015

Please cite this article as:

STŘEDOVÁ, H., SPÁČILOVÁ, B., PODHRÁZSKÁ, J., CHUCHMA, F. (2015): A universal meteorological method to identify potential risk of wind erosion on heavy-textured soils. Moravian Geographical Reports, 23(2): 56-62. DOI: 10.1515/mgr-2015-0011. 